\title{
Aisnusantara: Kontribusi Santri Membangun Narasi Damai di Era Digitalisasi Media
}

\author{
Naili Ni'matul Illiyyun, ${ }^{1 *}$ Ahmad Afnan Anshori, ${ }^{2}$ Helmi Suyanto ${ }^{3}$ \\ ${ }^{1}$ Universitas Islam Negeri Walisongo, Semarang - Indonesia, ${ }^{2}$ Radboud University \\ Nijmegen - The Netherlands, ${ }^{3}$ Bengkel Jurnal, Semarang - Indonesia
}

\begin{abstract}
Instagram has become a new lifestyle in recent years. Instagram has created a society without borders because its users and followers are not limited to places. Instagram users post creative photos and videos on their accounts not only for advertising but also network orientation. Millennial generation tends to use the internet in all aspects of life. This paper aims to pay attention to: 1) How about the model and strategy of the Millennial Muslim network in aisnusantara; and 2) How they explain the importance of religious moderation in digital media. This qualitative research uses a netnographic approach based on data from the @aisnusantara Instagram account. With the ethno-semiotic method, this research reveals that: 1) Aisnusantara uses a networking management model from the national to regional levels, and has an annual meeting, namely the Kopdarnas which has an agenda to discuss various issues related to national and religious affairs for the millennial generation. 2) Aisnusantara campaigned for Islamic preaching inclusively through Instagram, for example against extremism on social media, by offering alternative narratives to counter extremism by campaigning for peaceful Islam based on religious moderation.

Instagram telah menjadi gaya hidup baru dalam beberapa tahun terakhir. Instagram telah menciptakan masyarakat tanpa batas karena pengguna dan pengikutnya tidak terbatas pada tempat. Pengguna instagram memposting foto dan video kreatif di akun mereka tidak hanya untuk iklan tetapi juga orientasi jaringan. Generasi milenial cenderung menggunakan internet dalam segala aspek kehidupan. Makalah ini bertujuan untuk menyelidiki: 1) Bagaimana model dan strategi jaringan Muslim Milenial di aisnusantara; dan 2) Bagaimana mereka menjelaskan pentingnya moderasi beragama di media digital. Penelitian kualitatif ini menggunakan pendekatan netnografi berdasarkan pengumpulan data dari akun Instagram @aisnusantara. Dengan metode etno-semiotika, penelitian ini mengungkapkan bahwa: 1) Aisnusantara menggunakan model jejaring kepengurusan dari tingkat nasional hingga tingkat daerah, dan memiliki pertemuan tahunan yaitu Kopdarnas yang memiliki agenda membahas berbagai isu terkait urusan kebangsaan dan agama bagi generasi milenial, 2) Ainusantara mengkampanyekan dakwah Islam secara inklusif melalui Instagram, misalnya melawan ekstremisme di media sosial, dengan cara menawarkan narasi alternatif untuk melawan ekstremisme dengan mengkampanyekan Islam damai berdasarkan moderasi agama.
\end{abstract}

Keywords: religious moderation; netnography; the digital media; millennial Muslim

*Corresponding Author: Naili Ni'matul Illiyyun (naili.illiyyun@walisongo.ac.id), Jl. Prof. HAMKA, Kampus 3, Tambakaji Ngaliyan, Semarang 50185, Indonesia. 


\section{Pendahuluan}

Perilaku beragama masyarakat di Indonesia cukup dinamis. Hal ini disebabkan karena negara ini bukanlah masyarakat yang homogen, akan tetapi sangat beragam latar belakangnya. Selain itu, sejak era Reformasi tahun 1998, masyarakat Indonesia menuntut untuk penegakan demokrasi secara maksimal, tidak ada lagi pembatasan dan pengekangan dalam berpendapat di ruang publik sebagaimana terjadi dalam pemerintah sebelumnya. Sehingga, hal tersebut mengakibatkan penyampaian aspirasi publik menjadi sangat terbuka, misalnya seringnya terjadi demonstrasi, saling kritik, provokasi dan sebagainya. Imbasnya, kondisi sebagian masyarakat di Indonesia mudah terprovokasi hanya karena mengkonsumsi berita yang disajikan di berbagai media atau mungkin mendengarkan ceramah dari seorang ustadz yang berujung pada kebencian terhadap sesama.

Era revolusi Industri 4.0 membawa perubahan yang signifikan. Masyarakat terpapar media dengan sangat mudah tanpa mengenal usia dan batas geografis. Revolusi Industri 4.0 didefinisikan sebagai perubahan menyeluruh di dalam bidang produksi dimana internet menjadi inti penggeraknya (Prasetyo \& Sutopo, 2018: 19). Di era ini, ada generasi millennial atau seringkali disebut sebagai "generasi Y" yang mengalami dampak revolusi Industri 4.0. Generasi tersebut dituntut memiliki keterampilan dan kecakapan yang baik. Seiring berkembangnya waktu, terjadi kebutuhan berjejaring atau membentuk network cukup dibutuhkan oleh generasi millennial untuk menjawab tantangan zaman. Revolusi Industri 4.0 menawarkan bermacam-macam media sosial yang bisa dimanfaatkan oleh seluruh segmen dalam menghadapi pasar ekonomi global.

Merespon konten-konten di media sosial yang sangat beragam, tak terkecuali komunitas aisnusantara yang aktif di bidang dakwah Islam menggunakan media sosial seperti Instagram dalam membentuk jaringannya. Dari pengamatan penulis terhadap laman Instagram @aisnusantara, komunitas ini bertekad untuk mempromosikan perdamaian melalui media sosial melihat realita banyaknya konten-konten negatif dan mengarah pada gerakan ekstrim. Sejak tahun 2016, komunitas pegiat dakwah pesantren tersebut memiliki akun Instagram yang diberi nama @aisnusantara dan turut aktif meramaikan media sosial di kalangan santri Ahlus Sunnah Waljama'ah An-Nahdliyah sehingga jumlah followers akun tersebut mencapai lebih dari 51 ribu. Selain itu, komunitas tersebut aktif mengadakan kegiatan menarik seperti capacity building untuk anggota komunitas dan ajang silaturrahim yang mampu mengumpulkan sesama anggota komunitas tersebut.

Beberapa peneliti sudah melakukan kajian di bidang yang sama. Panjaitan meneliti korelasi antara produktivitas pekerjaan dan penggunaan media sosial di kalangan karyawan yang merupakan generasi millennial memiliki intensitas yang sering dalam menggunakan media sosial. Hasil risetnya menunjukkan bahwa penggunaan media sosial pada jam kerja di kalangan karyawan PT Angkasa Pura I Bandara Internasional Juanda mampu meningkatkan efektivitas dan efisiensi dalam pekerjaan mereka. Hal ini dikarenakan melalui media sosial tersebut (whatsapp), para karyawan mudah dalam melakukan koordinasi pekerjaan dan mengirimkan data 
(Panjaitan and Prasetya 2017:178). Selain itu, penelitian serupa dilakukan di industri perbankan oleh Luntungan et al. yang mendefinisikan generasi Y sebagai generasi yang lahir antara tahun 1984-1995 dan terpapar tekologi informasi. Ia menyebutkan beberapa karakter khas generasi tersebut yaitu berorientasi pada hasil daripada proses, memiliki sikap yang terbuka, dan pengaruh faktor lingkungan cukup dominan (Luntungan et al. 2014:237).

Dalam penelitian lainnya yang ditulis oleh Monaco dan Martin menyebutkan beberapa karakter siswa millennial cenderung pembelajar dengan model kolaborasi. Hal ini berbeda dengan zaman dahulu dimana siswa hanya mendengarkan ceramah sekaligus menerima bahan belajar disediakan oleh guru. Siswa sekarang lebih menyukai untuk mengkontrusi pengetahuannya daripada mendengarkan ceramah. Sehingga hal ini menuntut guru agar lebih siap dengan memposisikan diri sebagai fasilitator daripada penceramah (Monaco and Martin 2007:46).

Dalam penelitian di Amerika, generasi millennial diartikan sebagai yaitu orang yang lahir antara tahun 1980 hingga 2004 (Weinbaum 2016:1). Riset yang dilakukan Rand Corporation tersebut membidik dampak generasi millennial pada kecerdasan dan kebijakan publik. Hasilnya menunjukkan bahwa generasi tersebut memiliki tingkat kepercayaan yang rendah pada Pemerintah sehingga mereka menghendaki adanya kerjasama dan tanggung jawab bersama antara sektor swasta dan publik dalam mewujudkan cita-cita negara (Weinbaum, 2016: 39).
Penelitian Wahana menyebutkan bahwa karakteristik generasi millennial antara lain memiliki orang tua yang berpendidikan tinggi, penggunaan teknologi sebagai gaya hidupnya, berorientasi pada hasil yang serba instan, dan sebagainya (Wahana, 2015: 21).

Aisnusantara juga pernah diteliti dengan fokus yang berbeda. Penelitian yang dilakukan oleh Siti Husnul Fauziah fokus pada strategi gerakan literasi media digital kepada santri di Yogyakarta dan Ais Jogja sebagai objek penelitiannya (Fauziah 2018:84). Sedangkan penelitian lainnya dilakukan oleh Hasyim Iskandar tentang dakwah komunitas Ais Bayuwangi melalui literasi media digital santri. Penelitian tersebut menunjukkan bahwa Ais Banyuwangi bekerja sama dengan Komunitas Santri Desain Community dalam beberapa upaya yang dilakukan. Target dakwah yang dilakukan adalah santri di pondok pesantren, siswa-siswi di sekolah, dan mahasiswa (Iskandar 2018: 112).

Dalam kajian posmodern, kebudayaankebudayaan dimaknai secara plural dengan cara menerima perbedaan yang ada, di mana pluralitas menjadi salah satu ciri khas paradigma tersebut (Bauman dalam Jones 2010; Ritzer 2010). Berbeda dengan modernisme, dalam kerangka berpikir ini perbedaan kebudayaan diapresiasi dan diterima agar mampu berkomunikasi satu dengan yang lain (Ritzer 2010). Isu dalam penelitian ini menyajikan respon suatu komunitas terhadap keberagaman khususnya dalam ranah sosial keagamaan. Dalam paradigma posmodern, kebenaran bersifat relatif sehingga ditiadakannya penilaian moral benar dan salah. Akan tetapi, bagaimana ke- 
benaran tersebut direpresentasikan melalui media massa. Dalam kajian media, dikenal istilah kajian atau analisis resepsi di mana pertemuan teks dan khalayak media menjadi titik penting. Dalam analisis resepsi ini komunitas interpretif berupaya untuk mengklasifikasi dan memaknai teks walaupun hasilnya berbeda-beda terhadap suatu konten yang pada akhirnya diterima oleh masyarakat secara luas (Nasrullah 2019: 88-89). Khalayak media diartikan Nasrullah bukan sebatas penerima konten saja, akan tetapi khalayak tersebut memiliki beberapa karakteristik antara lain orang yang memperhatikan sebuah produk atau konten, orang yang menjadi sasaran pembuat konten, orang yang merespon hal yang sedang berlangsung, dan terakhir adalah sebagai pendengar aktif (Nasrullah 2019: 5-9).

Kehadiran media massa memvisualisasikan budaya populer atau yang lebih akrab disebut dengan budaya pop. Realitas dilihat dari representasi-representasi yang muncul di media, bukan melalui realitas itu sendiri (Pakulski dalam Turner 2012). Posmodern fokus pada budaya konsumsi. Budaya pop diminati banyak orang dalam bidang apapun. Salah satu contohnya yaitu aplikasi Instagram yang berhasil menarik minat baik di kalangan remaja maupun dewasa. Hal tersebut merespon era digital 4.0 yang menuntut orang agar mampu eksis di era yang serba digital melalui akun media sosial yang dimilikinya.

Revolusi industri 4.0 dikenalkan pertama kalinya di Jerman pada tahun 2011 di dalam even Hannover Fair (Kagermann, Lukas, and Wahlster 2011). Istilah lain yang dipakai untuk menyebut era ini adalah Smart Factories,
Industrial Internet of Things, Smart Industry, atau Advanced Manufacturing. Penggunaan istilah tersebut berbeda di setiap Negara walaupun memiliki tujuan yang sama yaitu pasar global dalam menyikapi teknologi informasi yang sangat pesat (Prasetyo and Sutopo 2018:18).

Selanjutnya, konsep kunci yang perlu diketahui adalah generasi millennial. Menurut Howe dan Strauss, generasi millennial yaitu mereka yang lahir antara tahun 1982-2002 dan memiliki karakteristik sebagai berikut: bersemangat dan menghargai sesama, pengikut aturan yang terstruktur, terlindungi, mudah bekerja sama dalam tim, multitalen, percaya diri dan optimis akan masa depannya (Elam, Stratton, and Gibson 2007:23). Definisi tersebut yang terbatas mengacu pada tahun kelahirannya mungkin tidak cukup untuk mendefinisikan generasi millennial atau generasi Y karena konteks sosial budaya juga harus dipertimbangkan dampaknya terhadap generasi tersebut (Luntungan et al. 2014:222). Sehingga akses terhadap teknologi informasi menjadi sangat penting dalam mendefinisikan generasi tersebut. Generasi millennial, menurut hasil survei nasional CSIS tahun 2017, mereka yakni pemuda dengan rentang usia 17-29 tahun lebih banyak menggunakan media sosial dibandingkan dengan generasi non-millennial. Misalnya generasi millennial yang memiliki akun Facebook sebanyak $81.79 \%$. Selain itu mereka juga merupakan pengguna Twitter, Whatsapp, BBM, Path, dan Instagram.

Penelitian ini merupakan penelitian kualitatif dimana fokus kajiannya berasal dari kontenkonten yang ada di dalam media sosial Instagram. Adapun teknik pengumpulan data dalam 
penelitian ini adalah netnografi. Metode tersebut sebagaimana dikenalkan oleh Kozinets mempunyai kemiripan dengan etnografi pada umumnya, hanya saja teknik netnografi ini mengambil datanya dari internet. Beberapa langkah yang harus dilakukan dalam netnografi, yaitu, perencanaan pelaksanaan riset, penyusunan rumusan masalah dan objek kajian dari media sosial, pengumpulan data, penafsiran data yang meliputi klasifikasi dan pengkodean data, pemenuhan standar etik penelitian, dan penyajian hasil penelitian (Kozinets 2002: 64; Bowler 2010: 1272). Adapun data dalam penelitian ini diperoleh dari akun Instagram @aisnusantara dengan melihat konten-konten akun tersebut secara keseluruhan. Selain itu, penulis menggali data dari anggota komunitas tersebut melalui wawancara semi terstruktur pada beberapa anggota komunitas ini serta penelusuran dokumen atau literatur yang sesuai dengan topik. Setelah data diperoleh, langkah selanjutnya adalah mereduksi data yang tidak terpakai kemudian mengklasifikasikan data-data tersebut.

Selanjutnya peneliti menganalisis data tersebut dari hasil pemetaan konten-konten @aisnusantara dengan menggunakan etnosemiotika (ethno-semiotics), yakni menafsirkan sebuah teks dengan mempertimbangkan keadaan sosial masyarakat yang melingkupinya. Barthes menggunakan istilah analisis makro yaitu konteks sosial yang ada di balik sebuah teks, dan analisis mikro yakni hal yang berkaitan langsung antara masyarakat dengan teks tersebut (Piliang 2003: 276; Denzin 2009: 618). Sehingga, pemaknaan data yang berupa kontenkonten aisnusantara yang sudah terklasifikasi tersebut selanjutnya dianalisis dengan melihat konteks sosial yang ada di sekelilingnya. Hal tersebut juga seringkali disebut sebagai etnografi virtual (Nasrullah 2017: 34).

Berdasarkan pemaparan di atas, maka penelitian ini bertujuan untuk mengetahui model dan strategi komunitas aisnusantara dalam berjejaring sesama generasi Muslim millennial. Selain itu, penulis juga ingin melihat pentingnya moderasi beragama di dunia digital. Komunitas aisnusantara secara aktif melakukan narasi alternatif dalam merespon sikap ekstrimis melalui dakwah toleran yang diusungnya dalam akun @aisnusantara berbasis pada prinsip moderasi beragama.

\section{Sejarah Komunitas Aisnusantara}

Lahirnya komunitas aisnusantara disambut positif oleh banyak pihak. Hal tersebut dimulai ketika Ahmad Qomaruddin, seorang santri Assiddiqiyah Jakarta, mempunyai inisiatif untuk membuat akun Instagram @galerisantri. Tak lama, ia menginisiasi ajang silaturrahim beberapa admin Instagram santri di Indonesia dan mendapat dukungan mereka. Pada tanggal 26 Oktober 2016 di Yogyakarta, kurang lebih 50 admin media sosial berkumpul untuk pertama kalinya dan membuat kesepakatan untuk meresmikan sebuah ruang dakwah "digital media networking" yang diberi nama aisnusantara.

Pemberian nama komunitas ini pun tidak lepas dari konteksnya. Pada mulanya komunitas ini bernama "Admin Instagram Santri". Namun, seiring berkembangnya waktu santri tidak hanya mengakses Instagram tetapi juga beberapa media sosial yang lain, sehingga nama komunitas tersebut berubah menjadi "Arus Informasi Santri Nusantara" atau disingkat aisnusantara sebagai ruang komunikasi dan 
diskusi para cyber media santri dalam menghadapi isu-isu aktual yang sedang berkembang. Aisnusantara memiliki tujuan untuk mengkampanyekan perdamaian melalui media sosial baik kepada sesama santri maupun dan umat manusia Indonesia pada umumnya.

Aisnusantara sangat diminati banyak orang di Indonesia. Hal ini tampak pada akun Instagram @aisnusantara yang sudah memiliki 51 ribu followers dan 1729 konten terhitung sejak akun Instagram tersebut dibuat pada tahun 2016 (data Agustus 2019). Selain itu, aisnusantara juga membentuk jejaring komunitas serupa untuk tiap daerah atau provinsi di Indonesia seperti @aisjawiwetan (Jawa Timur), @aisjawabarat (Jawa Barat), @ais.jawatengah (Jawa Tengah), @aisjogja (Yogyakarta), @ais_lampung (Lampung), @ais. Banten (Banten), @ais.aceh (Aceh), @aisbatavia (Jakarta), @ais. Ngapak (Banyumasan), @aiskalsel (Kalimantan Selatan), @aisbanyuwangi (Banyuwangi), dan @aisjember
(Jember). Anggota aisnusantara merupakan santri yang lahir antara tahun 1982 hingga 2002 dan mereka aktif dalam memanfaatkan media sosial sehingga memudahkan mereka dalam berkomunikasi dan berinteraksi.

Komunitas aisnusantara berjejaring dengan cukup baik dengan pegiat akun media sosial yang lain. Adapun media sosial yang dikelola oleh tersebut antara lain: Website, Facebook, Telegram, whatsapp, Twitter, Line, Youtube Channel dan beberapa media sosial lainnya. Tercatat lebih dari 500 akun media sosial dan portal website Islam Aswaja yang memiliki kesamaan visi dan misi tergabung dalam komunitas aisnusantara. Beberapa akun populer yang sudah tergabung dalam komunitas aisnusantara adalah: Alasantri, Santrikeren, Pesantrenstory, Galerisantri, Cahpondok, Santriputrihits, Nuonline, Nutizen, Islami.co, Dutaislam, TV9 Nusantara dan lainnya.

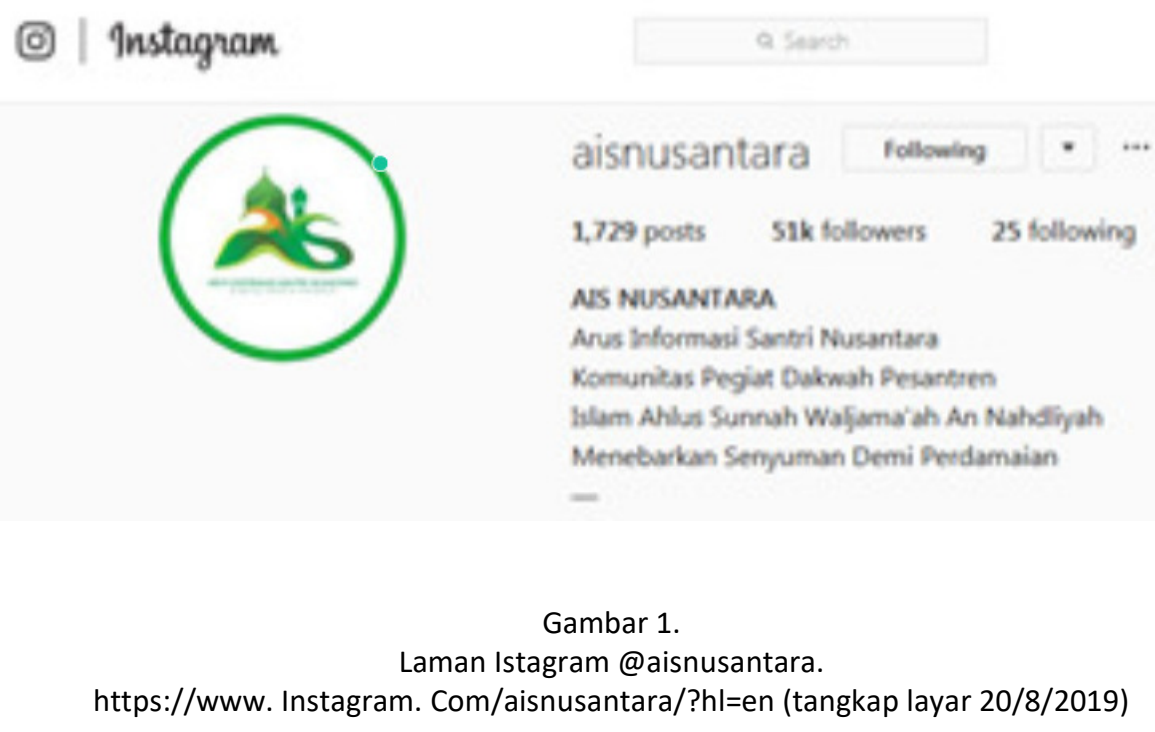

170

JSW (Jurnal Sosiologi Walisongo) - Volume 4, No. 2, 2020 
Hal ini senada ungkapan Krekovic bahwa internet dewasa ini telah berhasil membuat dimensi baru dalam pendidikan dan menjadi sumber pengetahuan terbesar di dunia. Hal ini membawa pengaruh besar khususnya bagi anak muda untuk berjejaring (Krekovic 2003: 8-9).

Aisnusantara berusaha memberikan manfaat positif pada komunitas melalui visi dan misi yang dimilikinya. Visi digitalisasi dakwah Ahlus Sunah wal-Jama'ah diterjemahkan dalam beberapa misinya, yaitu pertama, menjadi pusat informasi dan silaturrahim santri dan pesantren di seluruh Indonesia; kedua, menyajikan referensi ibadah yang berhaluan Aswaja; ketiga, mendorong pesantren di seluruh Nusantara memiliki akun media sosial sebagai pusat media dakwah dan komunikasi pesantren; keempat, menyajikan konten yang sejuk dan rahmatan li I-'âlamin.

Dalam konten yang diunggah oleh aisnusantara, gerakan mengkampanyekan \#indonesialebihnyantri terlihat begitu massif. Hal tersebut dikarenakan ada target yang ingin dicapai dimana target tersebut sejalan dengan tujuan aisnusantara secara umum. Pertama, aisnusantara meyakini secara utuh bahwa karakter seorang santri dibutuhkan untuk juga dimiliki oleh seluruh masyarakat Indonesia. Bukan hanya soal moral dan religiusitas yang menjadi keunggulan santri, tapi juga soal sikap toleransi dan gotong-royong yang sangat kental di masyarakat santri. Salah satu informan mengutip pernyataan Ki Hajar Dewantara bahwa pesantren adalah indigenous way of learning bangsa Indonesia, sehingga aisnusantara meyakini preservasi karakter otentik bangsa melalui lembaga pendidikan yang paling komprehensif dan sustainable yang bisa diperoleh di pesantren. Kedua, aisnusantara berharap lebih banyak santri yang masuk ke ruang profesional strategis di Negara ini. Di ruang agama, santri sudah sangat dominan dan kontribusinya sangat besar. Sehingga aisnusantara berharap keterlibatan lebih banyak santri di ruang pengabdian yang lain semisal ekonomi, finansial, medis, politik, sosial dan sebagainya. Pesantren berperan membentuk santri menjadi pribadi yang berintegritas dan mempunyai resiliensi yang tinggi. Dua karakter tersebut yang saat ini sangat dibutuhkan untuk pembangunan Indonesia.

Akun aisnusantara tidak bisa lepas dari peran penting penyedia konten-kontennya (content creators). Mereka berasal dari anggota komunitas sendiri yang mempunyai bakat di bidang layout dan desain grafis. Konten-konten tersebut tampak menarik dengan didukung kerja sama dengan beberapa pihak yang tergabung dalam jaringan/komunitas aisnusantara. Tak jarang konten tersebut merupakan konten lanjutan (repost) dari akun jejaring sebelumnya yang membuka ruang untuk mengundang partisipan secara lebih luas. Berikut ini beberapa kegiatan yang diinisiasi oleh komunitas aisnusantara selama kurang lebih 2 tahun berjalan berdasarkan konten-konten yang diunggah di dalam akun instagram aisnusantara.

\section{Model Komunitas Aisnusantara}

Berdasarkan konten-konten yang diunggah di akun @aisnusantara, penulis mengklasifikasikan unggahan tersebut dalam beberapa model. Pertama, aisnusantara mengkampanyekan gerakan inklusif dan moderasi beragama Aisnusantara dalam unggahan di akun Insta- 
Tabel 1.

Klasifikasi Konten Akun @aisnusantara

\begin{tabular}{|c|c|c|c|}
\hline No & Kegiatan Keagamaan Islam & Capacity Building & Isu Nasional dan Kemanusiaan \\
\hline 1 & $\begin{array}{l}\text { Kajian Fikih, seperti: hukum } \\
\text { kurban, hukum nikah, wudlu, } \\
\text { qadla shalat, jual beli }\end{array}$ & $\begin{array}{l}\text { Ngaji sosmed, literasi digital, } \\
\text { talkshow, madrasah desain, } \\
\text { dialog interaktif, dan bedah } \\
\text { buku }\end{array}$ & $\begin{array}{l}\text { Moderasi beragama dengan } \\
\text { quote/ meme tokoh-tokoh } \\
\text { inklusif (Gus Mus, Gus Dur, Said } \\
\text { Aqil Siraj, Cak Nun, Habib Luthfi, } \\
\text { Buya Hamka, Quraish Shihab }\end{array}$ \\
\hline 2 & Ucapan selamat hari besar Islam & Pembuatan video santri & $\begin{array}{l}\text { Ucapan selamat hari besar } \\
\text { Nasional }\end{array}$ \\
\hline 3 & $\begin{array}{l}\text { Kampanye gerakan } \\
\text { \#indonesialebihnyantri }\end{array}$ & Creative Entrepreneur Santri & Dakwah yang damai dan toleran \\
\hline 4 & Doa-doa & Expo Komunitas dan Bazar & $\begin{array}{l}\text { Bencana gempa di Lombok, banjir } \\
\text { di Pacitan }\end{array}$ \\
\hline 5 & $\begin{array}{l}\text { Khataman akbar, Tahlil } \\
\text { kebangsaan }\end{array}$ & $\begin{array}{l}\text { Beberapa perlombaan, seperti: } \\
\text { video pendek, desain meme, } \\
\text { iklan pesantren, pemilihan duta } \\
\text { santri nasional, lomba foto } \\
\text { Instagram, komik strip santri, } \\
\text { esai. }\end{array}$ & $\begin{array}{l}\text { Nasionalisme, apel kebangsaan } \\
\text { Ansor-Banser se-Provinsi Banten }\end{array}$ \\
\hline 6 & Petuah Qur'ani & Kopdarnas, Kopdarwil, halaqah. & $\begin{array}{l}\text { Isu-isu nasional aktual, relasi } \\
\text { dengan pemerintah }\end{array}$ \\
\hline
\end{tabular}

gramnya menunjukkan bahwa aisnusantara mempromosikan potret Islam inklusif yang menebar perdamaian atau sering kali mereka sebut dengan istilah dakwah perdamaian melalui Instagram. Konten yang berisi ajakan perdamaian melalui meme/quote ulama dan tokoh Muslim yang toleran seperti Abdurrahman Wahid, Musthofa Bisri, Quraish Shihab, Hamka, Habib Luthfi, dan sebagainya memenuhi beranda akun tersebut (lihat Gambar 2 dan 3).

Selain itu, Menteri Agama Lukman Hakim Saifuddin memberikan petuah ketika mengisi kegiatan Kopdar Akbar santrinet Nusantara. Menteri Agama sangat menghimbau untuk menyebar toleransi khususnya di media sosial sebagai media berdakwah dengan mengusung moderasi beragama. Hal tersebut senada dengan visi dan misi aisnusantara. Komunitas ini melibatkan pemerintah dalam melaksanakan kegiatan-kegiatan positif yang diinisiasi. Kegiatan tersebut diharapkan menjadi inspirasi bagi para santri dan masyarakat umumnya. Berikut foto yang ditampilkan pada Gambar 4 .

Kedua, meningkatkan kapasitas santri/ anggota aisnusantara dengan mengadakan kegiatan pelatihan. Kegiatan yang pernah dilakukan oleh komunitas tersebut antara lain: Ngaji sosmed, literasi digital, talkshow, madrasah design, dialog interaktif, bedah buku, creative entrepreneur santri, beberapa perlombaan dan sebagainya. Kegiatan-kegiatan tersebut mendatangkan narasumber baik dari kalangan santri sendiri maupun pakar dari luar sesuai dengan kebutuhan. Hal tersebut menunjukkan bahwa santri anggota komunitas aisnusantara tidak hanya pandai dalam bidang agama, akan tetapi membekali santri untuk mampu menjawab tantangan zaman sesuai dengan bakat dan minatnya. Akan 


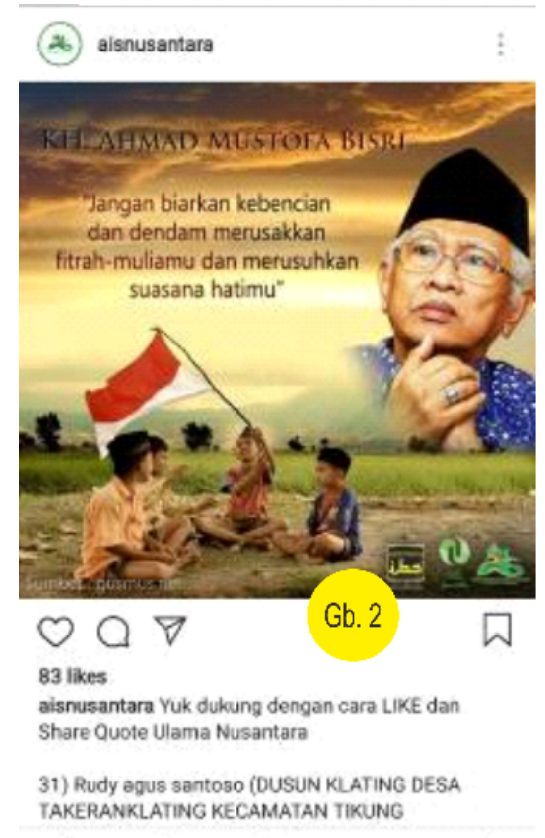

FIIKUNG

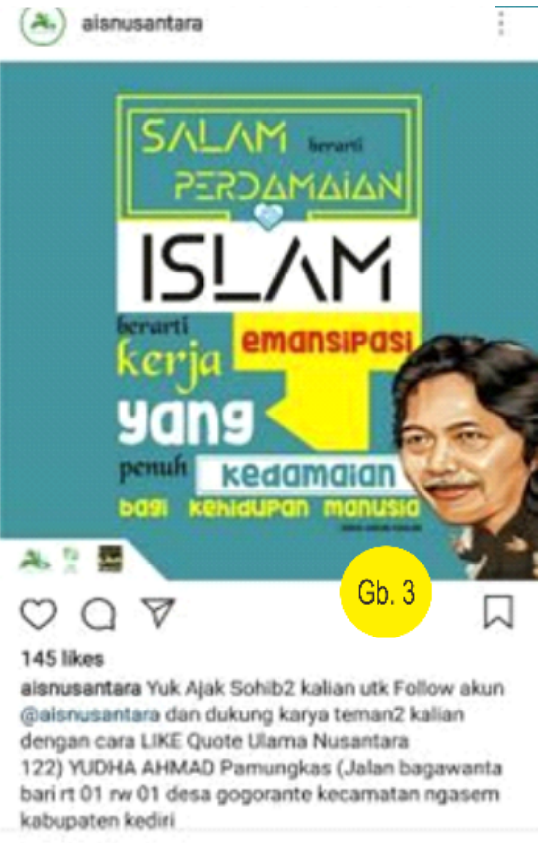

ก $\quad \oplus \quad 0$ 은

Gambar 2. Gus Mus (https://www.instagram.com/p/BNq3jqPj86P/) Gambar 3. Cak Nun (https://www.instagram.com/p/BNyZEXtjU6R/)

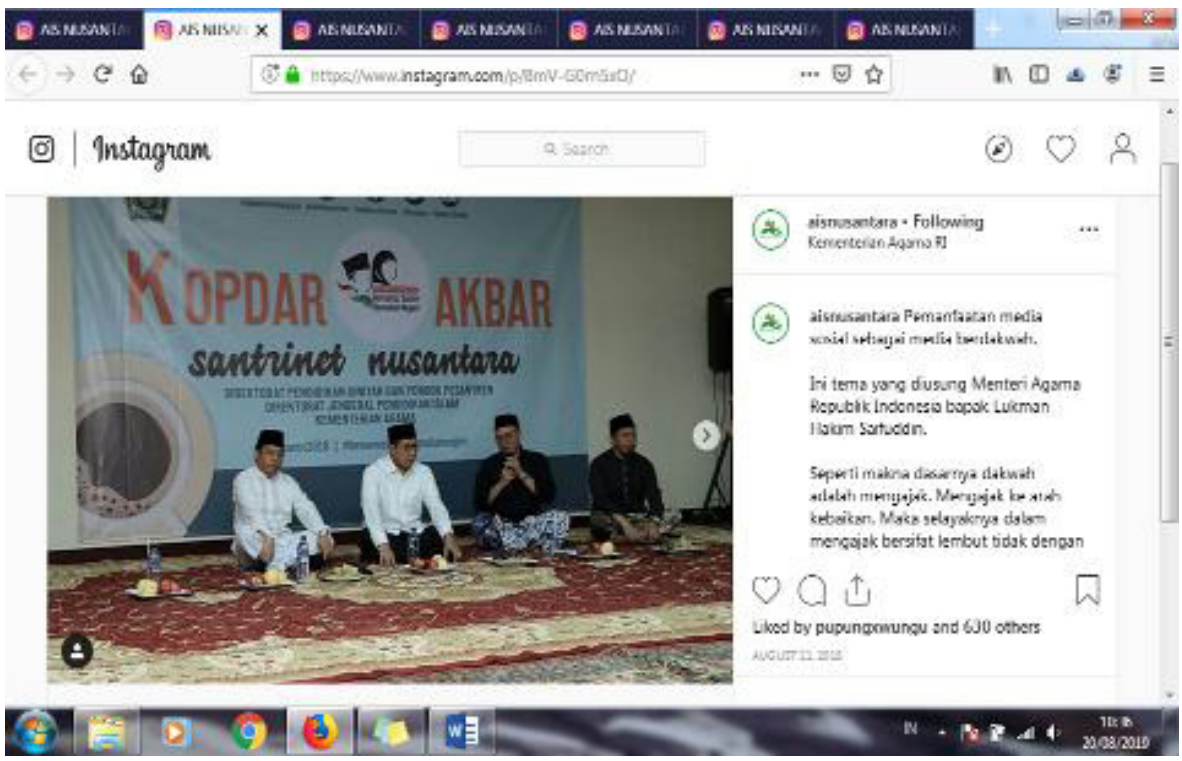

Gambar 4. Kopdar Akbar, dihadiri oleh Lukman Hakim Saifuddin (Menag) https://www.instagram.com/p/BmV-GOrn5xO/ - (tangkap layar 20/8/2019) 
tetapi, dalam hal capacity buiding tersebut, santri juga diharapkan tidak lupa dengan jargon aisnusantara yaitu dakwah rahmatan li l-'ālamīn sehingga terlihat dari unggahan yang berisi flyer perlombaan dengan tema-tema Islam dan toleransi (Gambar 5).

Kegiatan literasi media di kalangan santri menjadi concern aisnusantara sebagaimana ditampilkan dalam Gambar 6. Hal ini dilatarbelakangi banyaknya konten-konten negatif yang beredar di dunia maya sehingga harus ditanggulangi dengan bijaksana. Bentuk-bentuk kegiatan sebagaimana yang penulis tampilkan di atas merupakan upaya aisnusantara dalam memberikan pendidikan literasi media dengan konsep yang ringan dan ramah. Selain membekali peserta dengan keterampilan literasi, peserta juga diajak untuk mengkampanyekan
Islam yang rahmatan li l-ālamīn sebagaimana terlihat dalam potongan caption "penanganan konten negatif, serta produksi konten positif". Dalam konten lain yang diunggah, aisnusantara memvisualisasikan bahwa aisnusantara cinta damai dan anti-hoax. Deklarasi tersebut sebagai upaya mengajak netizen untuk mencegah aksi hoax yang sering terjadi di dunia maya. Aisnusantara juga bekerja sama dengan mitramitra yang kompeten dalam bidang tersebut dalam menginisiasi kegiatan dan tentunya mempunyai visi yang sama dengan aisnusantara.

Ketiga, mengadakan ajang silaturrahim berskala nasional dan regional, seperti Kopdarnas dan Kopdarwil. Kopdarnas (Kopi Darat Nasional) merupakan event terbesar dalam komunitas tersebut. Kegiatan ini sudah dilaksanakan empat kali sejak didirikan, yaitu:

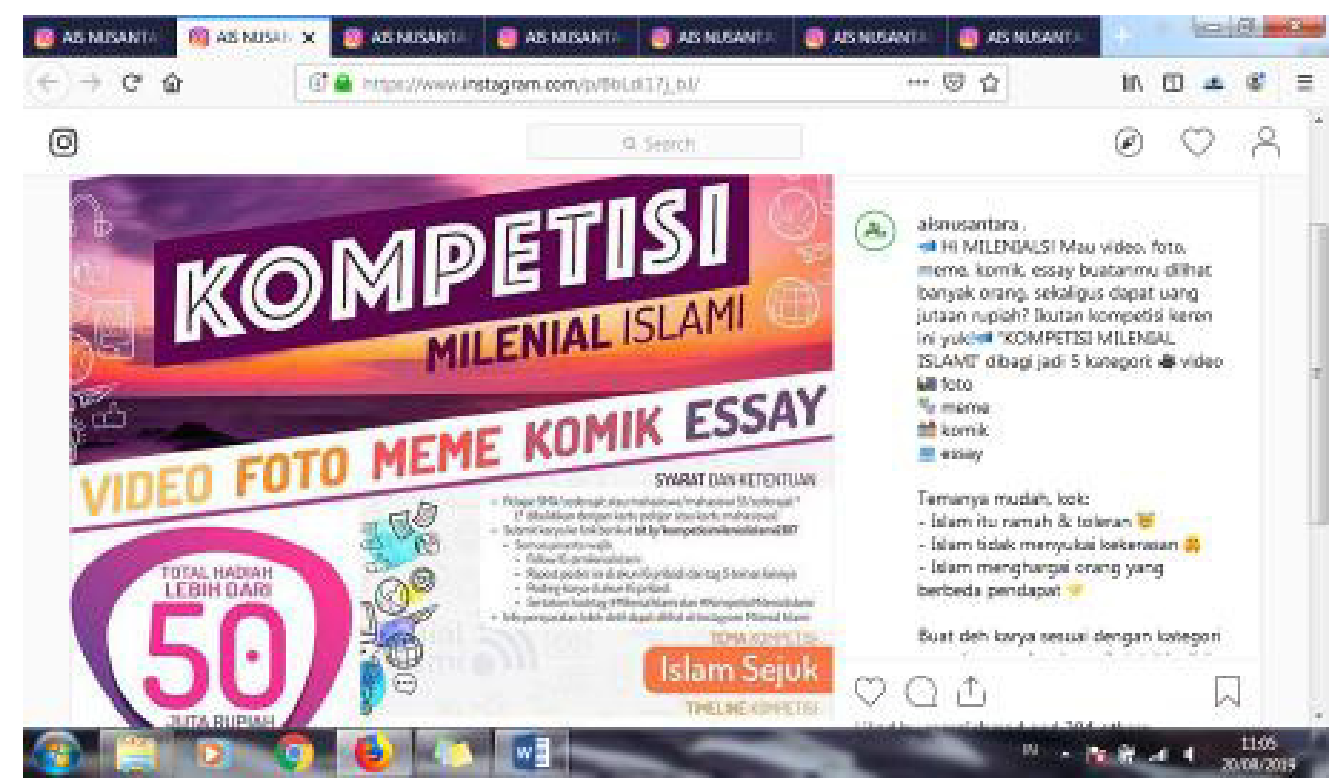

Gambar 5. Kompetisi Millennial Islami https://www.instagram.com/p/BbLdi17j_bJ/ - (tangkap layar 20/8/2019) 


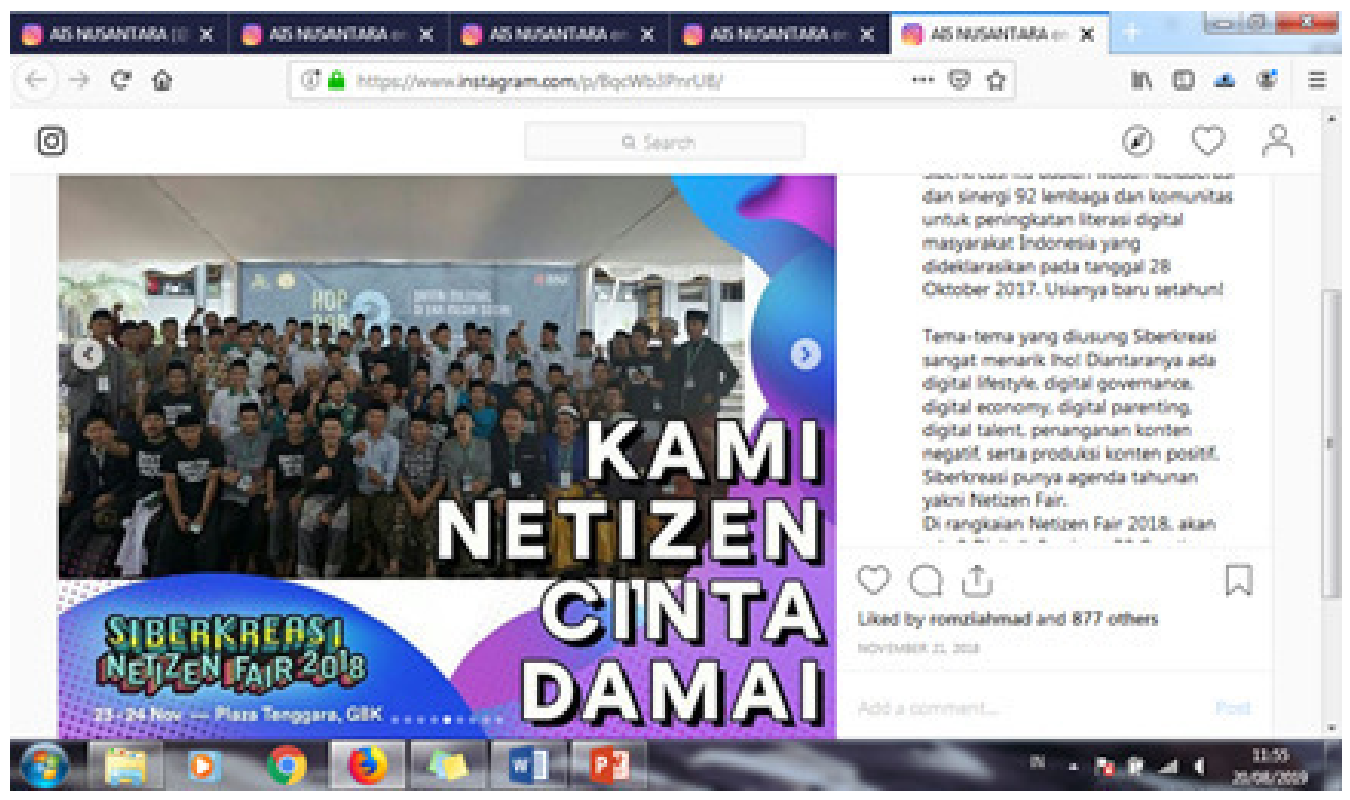

Gambar 6. Literasi Media SiberKreasi

https://www.instagram.com/p/BqcWb3PnrUB/ - (tangkap layar 20/8/2019)

1) Kopdarnas I dilaksanakan di Yogyakarta, 26 Oktober 2016; 2) Kopdarnas II dilaksanakan di Malang, 8-9 April 2017; 3) Kopdarnas III dilaksanakan di Bandung, 19-20 Oktober 2017; 4) Kopdarnas IV dilaksanakan di Pondok Pesantren An-Nawawi Berjan Purworejo Jawa Tengah, 7-8 Juli 2018.

Keempat, aisnusantara memperhatikan isu nasional dan kemanusiaan. Hal ini ditunjukkan dengan memposting konten isu perekonomian saat ini yang sedang dialami di negara ini dan memberikan semangat dan apresiasi pada atlet Asian Games. Dalam hal kemanusiaan, aisnusantara memberikan bantuan dan support kepada korban bencana alam seperti yang terjadi di Lombok, Pacitan dan sebagainya. Selain itu, aisnusantara juga memberikan support pada kajian gender. Hal ini terlihat dalam konten yang diunggah pada peringatan International Women's Day dengan judul "Santri Memandang Gerakan Perempuan". Penulis konten mengajak santri untuk bersikap responsif terhadap realitas sosial khususnya kemanusiaan. Hal tersebut dikuatkan dengan pandangan Musdah Mulia ditunjang dengan nilai Islam yang sangat manusiawi.

Kelima, aisnusantara mendakwahkan Islam melalui kajian fikih dan quote Qur'ani. Mayoritas anggota komunitas aisnusantara adalah santri Ahlus Sunnah wal-Jama'ah. Mereka saling berbagi ilmu terkait dengan kajian fikih yang berisi hukum-hukum muamalah maupun ibadah yang mungkin perlu diketahui atau diingat oleh komunitasnya. Kajian fikih yang ditampilkan dalam konten tersebut sangat kontekstual. Misalnya, hukum mengucapkan natal, hukum zakat 
profesi, hukum mandi dari hadats besar dan sebagainya. Dalam menjelaskan kajian fikih tersebut, aisnusantara menyertakan referensi yang dirujuk dalam menetapkan hukum-hukum tersebut. Selain itu, aisnusantara juga mengutip ayat-ayat qur'ani sebagai motivasi terpuji dan nilai profetik bagi komunitasnya.

Selain itu, sikap terbuka aisnusantara juga ditunjukkan dalam konten kajian fikih yang khusus membahas tentang ucapan selamat natal. Dalam konten tersebut menunjukkan bahwa asinusantara mengikuti madzhab yang memperbolehkan untuk memberikan ucapan natal bagi umat Kristiani. Terkait dengan konten tentang hukum mengucapkan selamat Natal mengundang banyak komentar (Gambar 7).

Netizen yang berkomentar pada konten di atas mayoritas tidak sepakat dengan konten tersebut dengan alasan merusak akidah. Padahal jika ditelusuri, konten tersebut memperoleh 780 likes. Alasan mereka adalah adanya kekhawatiran rusaknya akidah dengan mengucapkan selamat natal tersebut. Artinya dakwah digital yang dilakukan oleh aisnusantara mendapatkan respon yang luar biasa walaupun tidak semuanya mempunyai pendapat yang sama dalam hal penghormatan terhadap pemeluk agama lain.

Selain itu, aisnusantara merupakan komunitas yang terbuka juga dengan pemeluk agama lain. Hal tersebut ditunjukkan dengan konten yang diunggah dalam akun aisnusantara. Aisnusantara memberikan model yang patut dicontoh sebagaimana terlihat dalam Gambar 8 dengan mengutip quote Habib Luthfi dan pada Gambar 9 dengan mengutip Hadits Nabi SAW.
Dalam konten-konten tersebut, terlihat bahwa ajakan untuk menghormati manusia penting dilakukan. Pada Gambar 8 berisi pesan habib Luthfi bagaimana berelasi dengan umat Kristen. Habib Luthfi mengutip kisah Sayyidina Ali RA ketika melakukan shalat di gereja dan pendeta di gereja tersebut mempersilakan.

Pada konten Gambar 9 berisi tentang menjaga relasi dengan pemeluk agama Yahudi. Rasulullah saw memberikan contoh ketika ada jenazah orang Yahudi yang akan dimakamkan dan melewati depan Rasulullah, beliau berdiri untuk menghormati umat agama lain dengan alasan kemanusiaan.

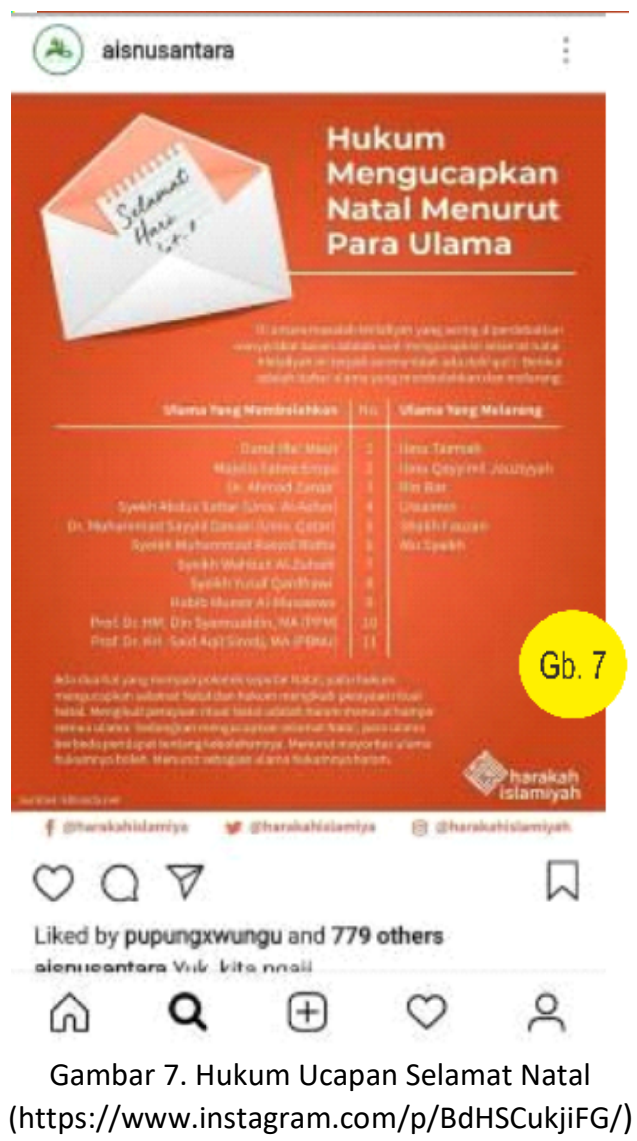




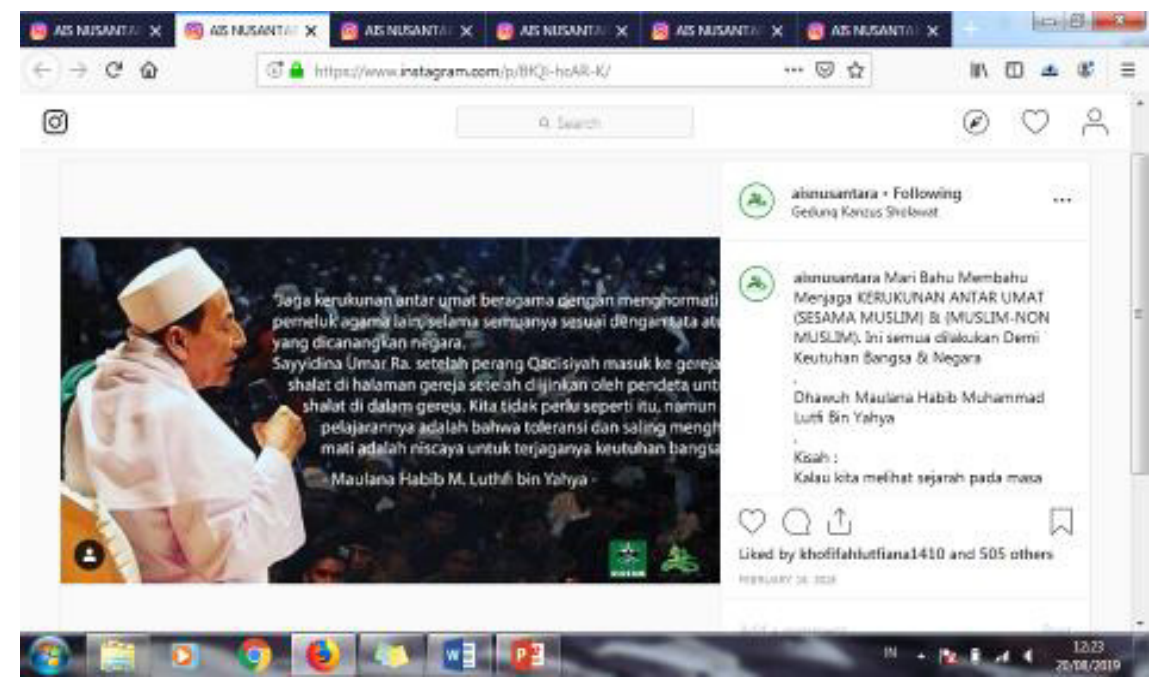

Gambar 8. Quote Habib Luthfi https://www.instagram.com/p/BfQI-hcAR-K/ - (tangkap layar 20/8/2019)

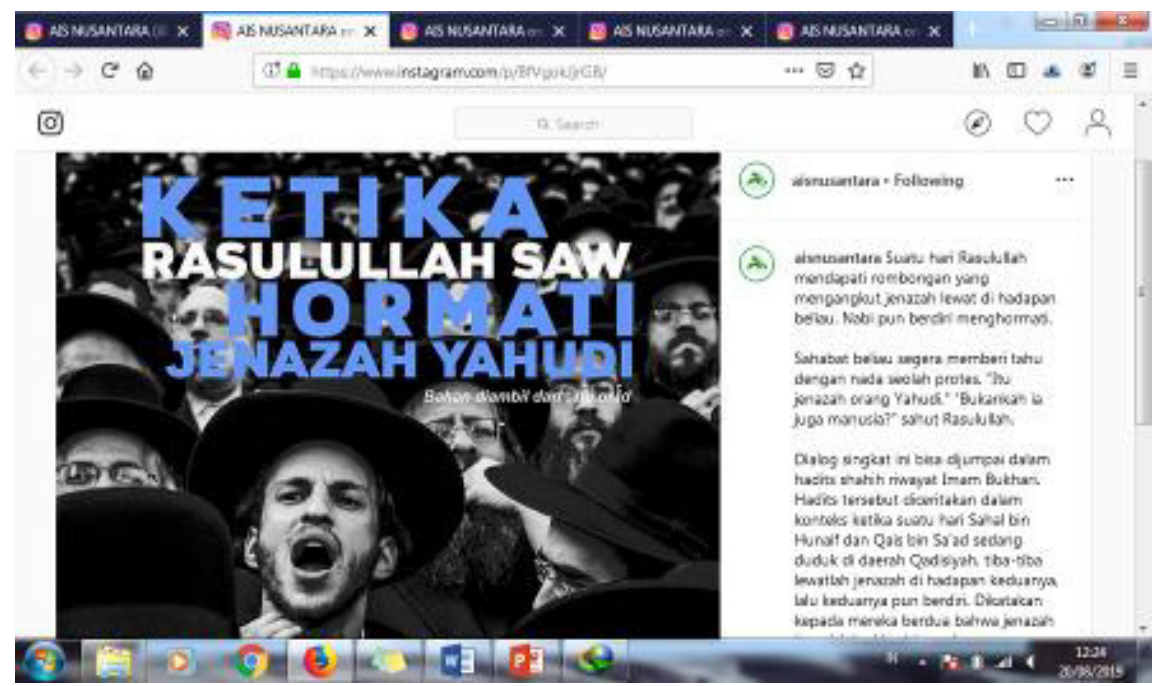

Gambar 9. Hubungan dengan Yahudi https://www.instagram.com/p/BfVgokJjrGB/ - (tangkap layar 20/8/2019)

Keenam, memvisualisasikan pentingnya menjaga keutuhan NKRI. Hal ini terlihat dalam unggahan aisnusantara yang mengutip motivasi dari Habib Luthfi dalam unggahan aisnusantara agar menghindari perpecahan. Selain itu, konten lain berisi acara Apel Kebangsaan yang diikuti oleh seluruh kader Ansor- Banser se-Provinsi Banten diadakan di Serang tanggal 25 Agustus 
2018. Dalam acara tersebut hadir Abuya Muhtadi, salah satu ulama di Banten. Selain itu, aisnusantara mengajak para santri untuk berkompetisi pembuatan video berdurasi 1 menit dengan tema cinta NKRI.

\section{Strategi Aisnusantara dalam Mewujudkan Muslim Millennial yang Moderat}

Berdasarkan konten-konten yang diunggah tersebut, aisnusantara menunjukkan bahwa komunitasnya memiliki intensitas yang tinggi dalam bersinggungan dengan teknologi informasi dalam era Revolusi Industri 4.0. Ada beberapa karakteristik yang dimiliki oleh generasi millennial sebagaimana disebutkan oleh Howe dan Strauss (2000): pertama, memiliki semangat yang tinggi dan menghargai sesama. Hal ini ditunjukkan dari antusias anggota komunitas aisnusantara dalam mengkampanyekan Islam damai melalui kegiatan-kegiatan dan kontenkonten instagramnya.

Kedua, generasi ini merupakan pengikut aturan yang terstruktur. Anggota aisnusantara di seluruh Indonesia berada dalam satu komando walaupun di tingkat regional mereka membentuk komunitas disesuaikan dengan daerah masing-masing. Akan tetapi, mereka berada dalam satu aturan dan visi dalam mendakwahkan Islam yang sejuk dan damai pada generasi millennial.

Ketiga, kelompok ini mudah bekerja sama dalam tim. Aisnusantara melibatkan berbagai pihak dalam menginisiasi kegiatan. Beberapa pihak yang pernah dilibatkan dalam kegiatan aisnusantara antara lain: KEMENAG RI, PBNU, RMI NU, LTN NU, SIBERKREASI dan beberapa jaringan media seperti Nuonline, Nutizen, Islami. Co, Dutaislam, dan TV9 Nusantara. Selain itu, perkembangan komunitas aisnusantara baik dalam ranah nasional maupun regional semakin pesat. Sehingga ada banyak akun Instagram aisnusantara tingkat regional sebagai tangan panjang komunitas tersebut. Anggota aisnusantara tersebar luas di Indonesia, mereka saling berkomunikasi dan berinteraksi di dunia maya dalam mengkonsep kegiatan. Kemampuan team work sangat diperlukan dalam membangun solidaritas antar anggota komunitas guna mewujudkan tujuan bersama.

Keempat, pemuda yang multitalen, percaya diri dan optimis akan masa depannya. Aisnusantara memfasilitasi beberapa kegiatan dalam rangka pengembangan bakat dan minat anggotanya. Program capacity building yang dikemas dalam kegiatan yang menarik. Misalnya perlombaan poster, meme, komik santri, esai dan sebagainya. Selain itu pelatihan literasi dan sosial media juga sering dilakukan. Dalam hal finansial, misalnya, aisnusantara mengadakan pelatihan kewirausahaan bagi anggotanya. Kegiatan tersebut cukup inspiratif dikarenakan narasumber kegiatan tersebut berasal dari komunitas sendiri. Artinya, tidak ada alasan bagi seorang santri untuk maju dalam bidang finansial karena semua orang mempunyai hak yang sama. Sejalan dengan target yang ingin dicapai oleh aisnusantara, komunitas tersebut disiapkan agar santri mampu menjawab persoalan zaman dan berkontribusi dalam membangun Negara ini dengan cara mengisi pos-pos strategis di berbagai bidang.

Generasi millennial yang ada di dalam komunitas aisnusantara akan selalu mengalami per- 
kembangan. Dalam menghadapi kondisi tersebut, diperlukan beberapa strategi untuk memelihara solidaritas dan karakter aisnusantara. Potret santri yang terbuka dengan perkembangan zaman dan mempunyai misi mendakwahkan Islam melalui media digital merupakan ciri khasnya. Ada beberapa strategi yang dilakukan komunitas aisnusantara dalam mempromosikan Muslim millennial yang inklusif.

Strategi pertama yang dilakukan aisnusantara melalui kegiatan-kegiatan yang diselenggarakan mempunyai misi yang salah satunya adalah menyajikan konten yang sejuk dan rahmatan lil'alamin. Hal ini penting dilakukan karena bertujuan untuk meminimalisir kebencian dan sikap intoleran yang akhir-akhir ini sering terjadi di Indonesia yang banyak digaungkan oleh kelompok ekstrimis melalui media sosial. Berdasarkan konten-konten yang diunggah di akun instagram, aisnusantara tidak pernah menyajikan konten-konten berisi SARA atau yang bersifat provokatif. Aisnusantara di tataran grassroots level mempunyai andil yang cukup kuat dalam mempromosikan Islam yang cinta perdamaian.

Selain itu, dalam menghadapi era Industri 4.0, aisnusantara menyiapkan anggota komunitasnya dengan menyelenggarakan kegiatan capacity building. Dalam menginisiasi kegiatan tersebut, aisnusantara bekerja sama dengan pihak-pihak lain misalnya lintas komunitas, organisasi, atau bahkan dengan pemerintah dan tokoh agama maupun tokoh masyarakat. Hal tersebut disambut positif oleh berbagai pihak dalam penyelenggaraan kegiatan yang sudah berjalan.

Terakhir, aisnusantara bersikap kooperatif dengan pemerintah Indonesia saat ini. Hal ini dibuktikan dengan mendukung beberapa kegiatan pemerintahan seperti Asian Games, menyemarakkan peringatan Hari Santri dengan mengemas tema Bandung Lautan Santri dan mengundang Walikota Bandung Ridwan Kamil beserta istri. Selain itu, aisnusantara juga dilibatkan oleh Kementerian Agama dalam launching logo dan rangkaian acara dalam rangka memperingati hari santri 22 Oktober mendatang. Kegiatan tersebut diselenggarakan pada tanggal 10 Agustus 2018 lalu. Aisnusantara tidak terlibat dalam politik praktis, akan tetapi komunitas tersebut memberikan support kepada Pemerintahan Jokowi dalam mensukseskan program membangun Negara Indonesia.

\section{Pentingnya Moderasi Beragama di Era Digital}

Pemerintah Indonesia melalui Kementerian Agama sedang gencar mempromosikan moderasi beragama di tengah keberagaman masyarakat. Salah satu inisiasi yang dilakukan adalah kegiatan literasi maupun aksi. Dalam kegiatan literasi, Kementerian Agama menerbitkan buku saku berjudul Tanya Jawab Moderasi Beragama pada tahun 2019 yang berisi tentang definisi dan contoh-contoh implementasi moderasi beragama dikemas dalam bahasa ringan agar mudah dimengerti.

Selain itu, pentingnya moderasi beragama juga ditekankan dalam akhir buku tersebut. Kegiatan aksi dalam mempromosikan moderasi beragama sudah banyak dilakukan sebagaimana terlihat dalam kegiatan yang diinisiasi oleh aisnusantara. Akan tetapi, penyebaran paham ekstremisme juga kian massif dan dinilai berbahaya bagi kerukunan umat beragama di Indonesia. Kata ekstrim di-definisikan sebagai pelanggaran dari norma yang berlaku (Borun 


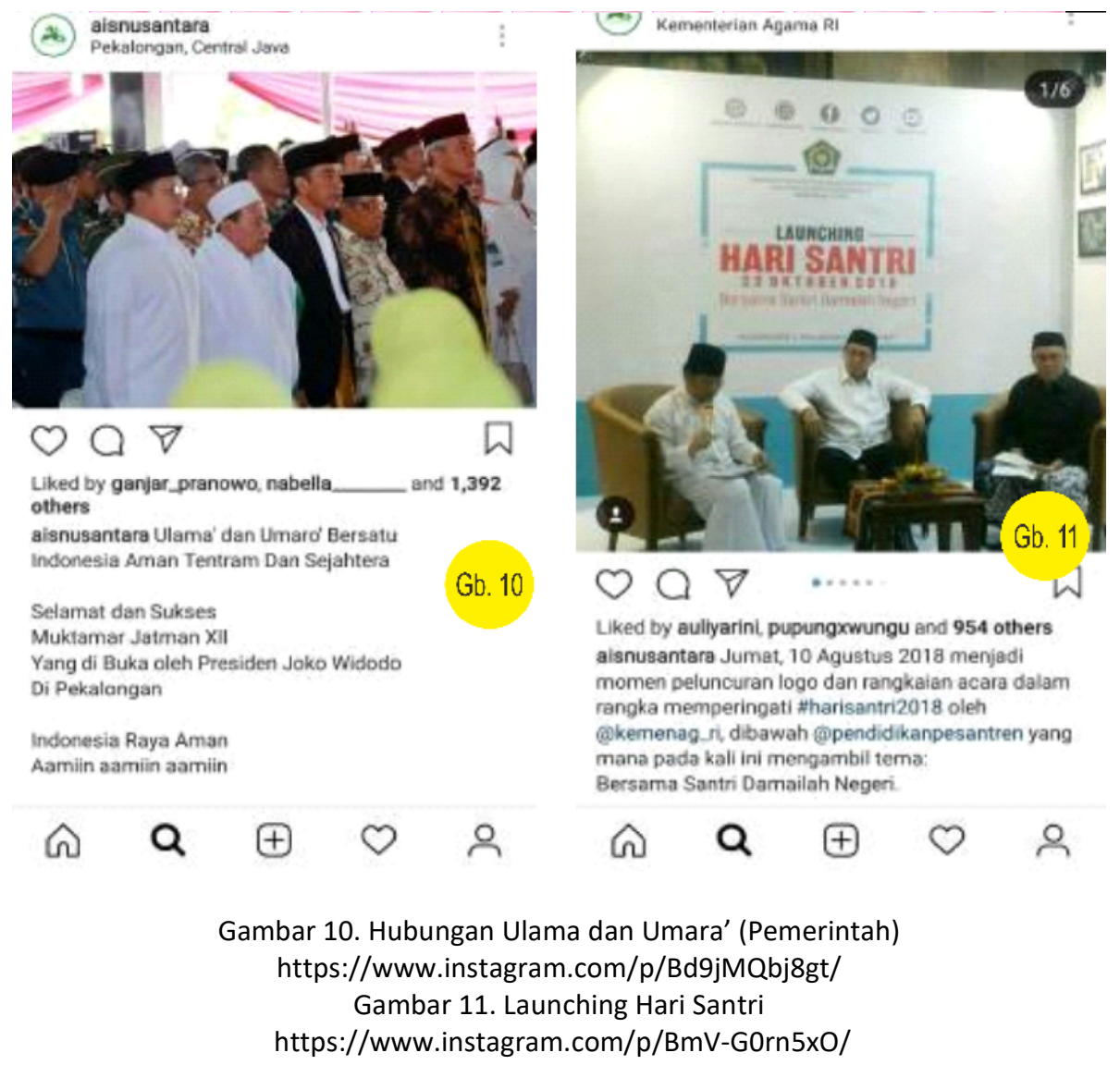

2011: 9). Sedangkan ekstremisme diartikan oleh Neuman (2010) (dalam Borum 2011: 10) sebagai paham yang mengacu pada ideologi politik yang berlawanan dengan prinsip dan nilai universal masyarakat pada umumnya.

Konten-konten eksklusivisme cukup massif di media sosial. Salah satu akun ekstrimis adalah @salamdakwah. Akun tersebut memiliki 198 ribu followers dengan jumlah 903 konten yang diunggah. Hal tersebut cukup disayangkan karena jumlah pengikut akun ini jauh lebih banyak dibandingkan dengan @aisnusantara. Karakter yang menonjol dalam setiap konten yang diunggah akun tersebut adalah pemahaman agama yang tekstual karena paham yang dianut merupakan paham salafi, sebagaimana yang ada pada Gambar 12 .

Selain itu, klaim syiah sebagai aliran sesat juga ditemukan dalam konten di bawah ini. Tak hanya itu, dalam akun tersebut juga disebutkan secara jelas larangan merayakan tahun baru karena dikaitkan dengan penggunaan kembang api dalam perayaan tersebut sehingga disamakan dengan menyembah api sebagaimana ritual yang dilakukan oleh umat Majusi (Gambar 13 dan 14).

Tak hanya akun tersebut, konten yang berisi ajaran ekstrimis tersebar meluas di media sosial khususnya Instagram dengan nama akun yang beragam. Terlebih jika seseorang mencari 


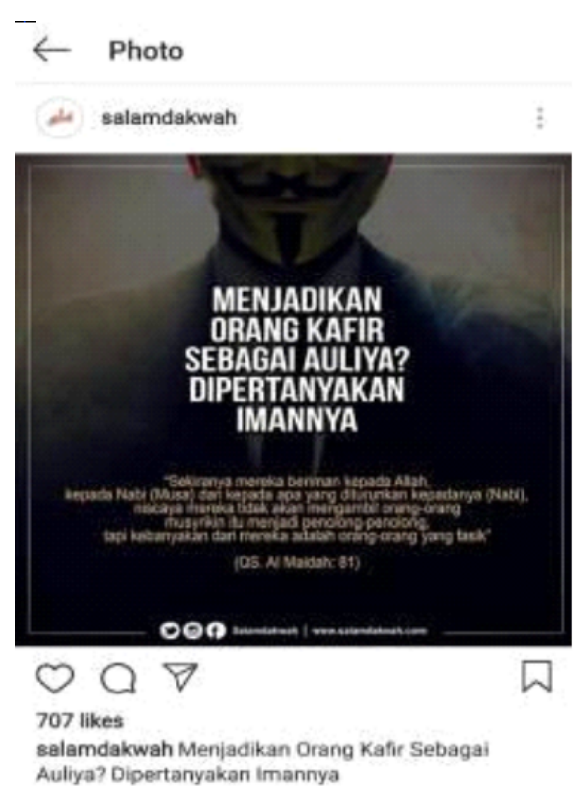

Auliya? Dipertanyakan imannya

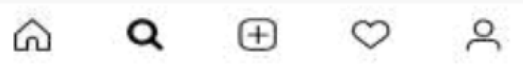

salamdakwah Andai Anda Jadi Presiden

Demo lagi demo lagi. Celaan demi celaan, tuntutan demi tuntutan, hingga bermuara pada rencana melengserkan sang presiden. Itulah secuil dari kerusakan yang sangat banyak akibat sistem demokrasi ala barat. Tidakkah kita berpikir sejenak "Andai kita jadi presider', mampukah kita menurnaikan arnanah berat jabatan presiden?

Jika anda berhasil menjadi imam yang adil di antara balasannya Anda mendapat naungan Allah di hari yang tiada naungan kecuali naungan-Nya, namun tahukah Anda adili itu bagaimana?

Ulama telah menjelaskan tentang ciri pokok keadilan seorang imam adalah berhukum dengan Syariat Islam, maka barangsiapa yang tidak berhukum dengan syarīat Islam ia bukanlah imam yang adil, litulah tafsiran imam adil yang terbaik. Artinya, jika Anda menjadi prosiden, maka perlu memiliki ilmu syariat isłam yang dalam dan keberanian untuk berhukum dengannya di tengahtengah arus hukum yang batil.

Berat? Jika Anda merasa tidak mampu menjadi kepala negara yang baik maka do'akanlah presiden Anda!

Doakan semoga Allah memberi petunjuk kepadanya, berilah nasihat dengan adab lslami dan jangan cela beliau di hadapan publik.

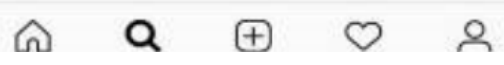

Gambar 12. Konten dalam akun @salamdakwah
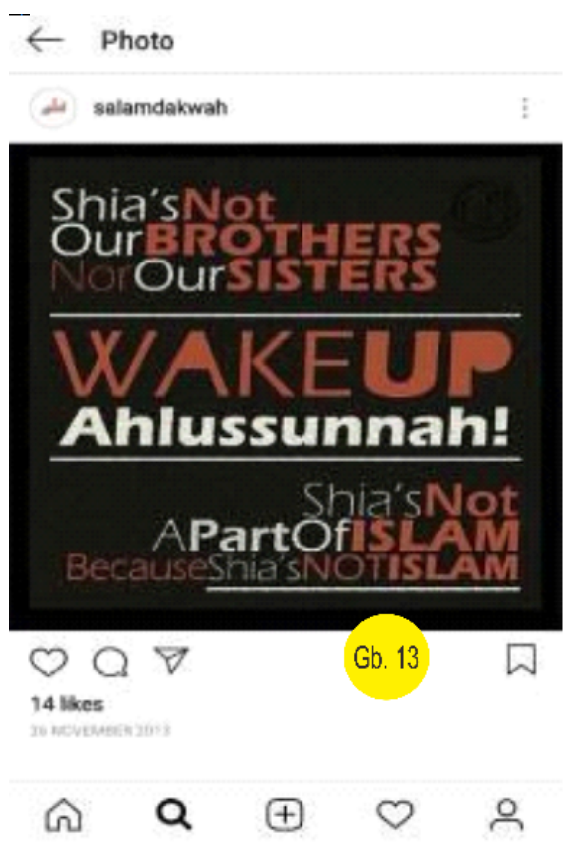
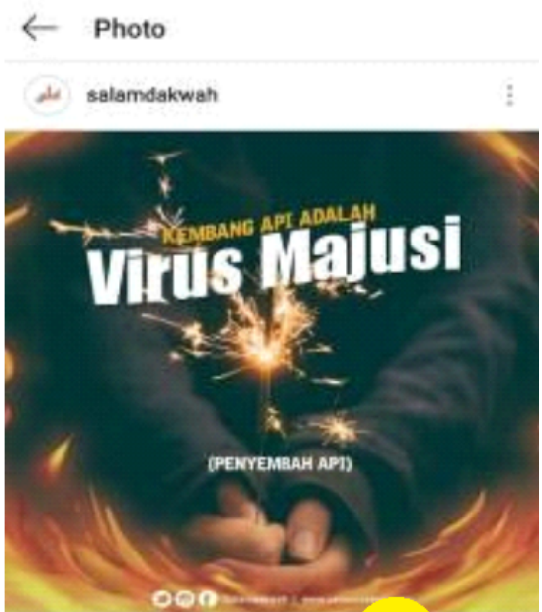

$\odot \bigcirc \nabla$

Gb. $14 \square$

465 likes

salamdakwah PERAYAAN TAHUN BARU DARI PERSPEKTIF AL-WALA' \& AL BARA'

Gambar 13. Penyesatan terhadap Syi'ah (@salamdakwah) Gambar 14. Hukum Perayaan Tahun Baru (@salamdakwah) 
konten dengan hashtag \#kafir \#sesat \#jihad \#khilafah \#syirik maka akan sangat mudah didapatkan konten-konten terkait. Misalnya \#kafir di Instagram sekarang ini telah ada 60. 521 konten yang diunggah dalam akun yang berbeda-beda.

Aisnusantara tampil sebagai respon ekstremisme yang berkembang di media sosial. Namun, aisnusantara tidak hanya berhenti di tataran media sosial, akan tetapi komunitas tersebut juga mengadakan aksi dan kegiatan positif melalui beberapa strategi yang telah dipaparkan di atas. Ada 2 bentuk narasi dalam media sosial yang dikemukakan oleh Fauzi dan Zainuri. Pertama, kontranarasi sebagai narasi yang diciptakan untuk membantah adanya ujaran kebencian yang bertujuan untuk mengungkap dan melawan ujaran tersebut (Fauzi dan Zainuri 2019).

Sedangkan bentuk narasi yang kedua adalah narasi alternatif yaitu narasi yang menawarkan perspektif dalam melihat suatu masalah kepada khalayak sebagai alternatif yang positif atas ideide yang lain (Setiyawati, dkk dalam Fauzi dan
Zainuri 2019: 137-138). Aisnusantara memilih narasi alternatif dalam mengkampanyekan perdamaian di media sosial. Adapun bentuk narasi alternatif yang diciptakan oleh aisnusantara sebagaimana konten berikut (Gambar 15 dan 16).

Moderasi beragama cukup massif dikampanyekan di akun aisnusantara. Moderasi berasal dari kata al-wasathiyyah atau wasathan di sini diartikan sebagai sikap tengah atau tidak berlebihan (Balai Diklat Kementerian Agama, 2019: 2; Fahri \& Zainuri, 2019: 96). Dalam konteks beragama aisnusantara memposisikan diri sebagai Muslim yang moderat dengan memegang teguh prinsip adil dan berimbang dalam mengamalkan ajaran agama Islam. Terlihat dari unggahan konten-konten yang ada di beranda akun Instagramnya. Konten pada gambar-gambar di atas. Konten tersebut diunggah ketika awal akun tersebut dibuat yakni pada tanggal 9 Desember 2016. Gambar 15 mendapatkan 138 likes, sedangkan Gambar 16 dengan 107 likes.



Gambar 15. Quote Gus Dur - https://www.instagram.com/p/BNyFIHGj55U 


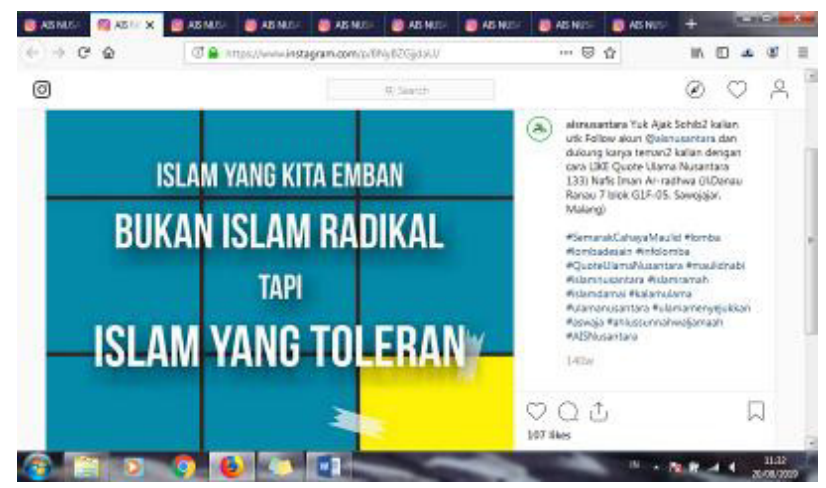

Gambar 16. Quote Islam Toleran

https://www.instagram.com/p/BNyBZGjjdaU/ (tangkap layar 17/12/2019)

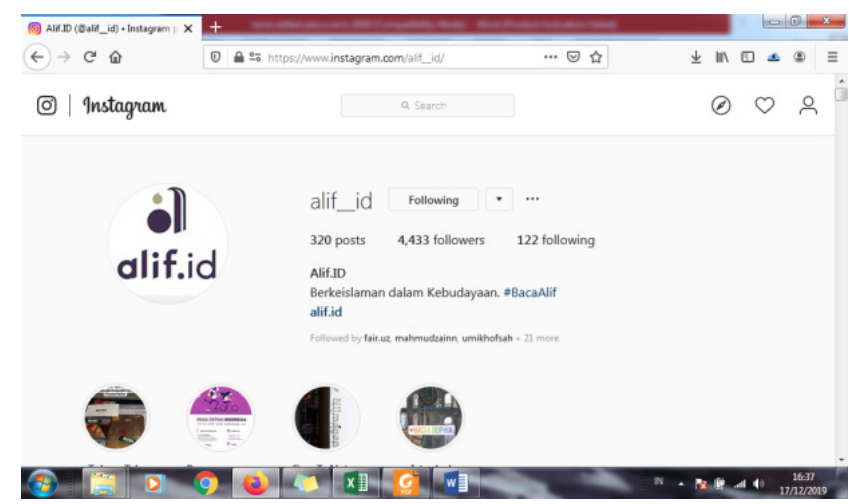

Gambar 17. Tampilan Akun @alif.id - https://www.instagram.com/alif_id/ (tangkap layar 17/12/2019)

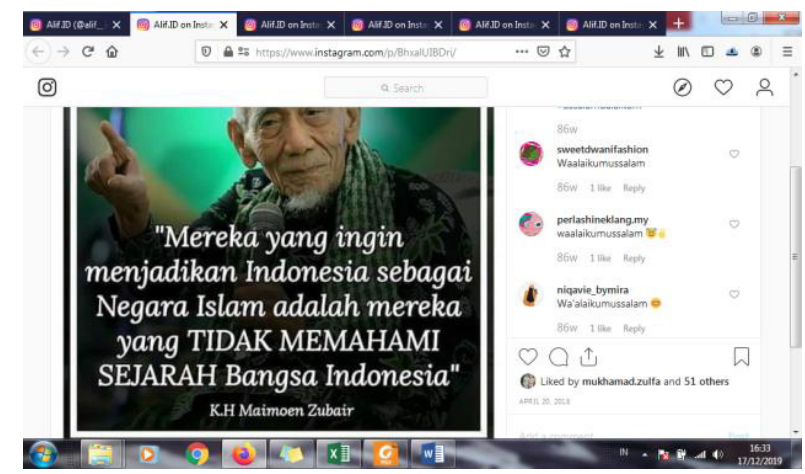

Gambar 18. Quote Kiai Maemoen Zubair dalam @alif.id https://www.instagram.com/p/BhxalUIBDri/ - (tangkap layar 17/12/2019) 
Keterlibatan media yang sesuai dengan visi aisnusantara juga turut membantu kontranarasi kebencian. Selain itu, aisnusantara juga aktif melibatkan pihak-pihak yang berpengaruh untuk mengkampanyekan perdamaian sebagaimana yang sudah dipaparkan di atas. Hal tersebut merupakan modal utama dalam melawan arus kebencian yang berkembang di masyarakat.

Meski demikian, aisnusantara bukanlah satusatunya komunitas yang berjuang melawan ujaran kebencian dan intoleransi di dunia maya. Alif_id misalnya, akun yang memiliki 4.433 followers juga secara aktif menyemai perdamaian dengan slogan berkeislaman dalam ke- budayaan seperti dalam konten berikut (Gambar 17 dan 18).

Selain alifid, akun nuonline_id juga massif mengkampanyekan toleransi. Akun yang dikelola oleh Pengurus Besar Nahdlatul Ulama' (PBNU) tersebut hampir memiliki pola yang sama dengan aisnusantara karena berasal dari latar belakang yang sama yakni Nahdlatul Ulama'. Akun tersebut memiliki 635 ribu followers dengan 5.497 konten yang diunggah dalam berandanya. Namun, aisnusantara terkesan lebih millennial jika dilihat dari kontenkontennya (Gambar 19 dan 20).

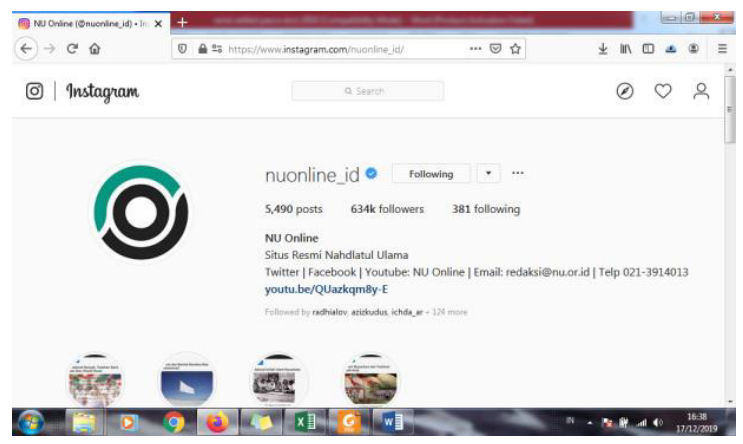

Gambar 19. Tampilan Akun @nuonline_id - https://www.instagram.com/nuonline_id/ (tangkap layar 17/12/2019)

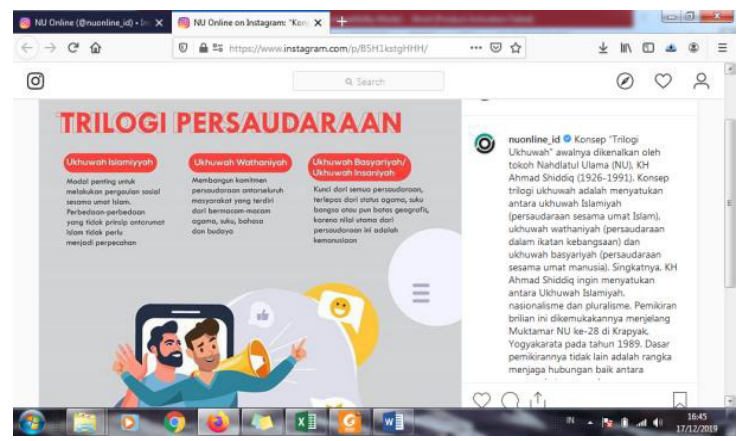

Gambar 20. Tampilan Konten @nuonline_id

https://www.instagram.com/p/B5H1kstgHHH/ (tangkapan layar 17/12/2019) 


\section{Kesimpulan}

Aisnusantara sebagai komunitas dakwah Islam memiliki model dalam membangun jaringan lintas santri. Penulis mengklasifikasi enam model yang dilakukan oleh komunitas aisnusantara, yaitu: mengkampanyekan gerakan toleran dan moderat, meningkatkan kapasitas santri/anggota aisnusantara seperti pelatihanpelatihan, mengadakan ajang silaturrahim berskala nasional dan regional, memperhatikan isu nasional dan kemanusiaan, mendakwahkan Islam melalui kajian fikih dan quote Qur'ani, serta memvisualisasikan pentingnya menjaga keutuhan NKRI.

Selain itu, dalam mempromosikan diri sebagai komunitas Muslim millennial yang toleran, aisnusantara memiliki beberapa strategi. Pertama, memberikan konten-konten bermanfaat dan mendukung dakwah Islam rahmatan $l i$ I'álamìn. Kedua, menyelenggarakan kegiatan capacity building untuk membekali anggota komunitasnya dalam menghadapi era Revolusi Industri 4.0. Ketiga, bersikap kooperatif dengan pemerintahan dalam memajukan Indonesia. Selain itu, konten-konten yang diunggah dalam akun aisnusantara juga sebagai upaya melakukan narasi alternatif dalam merespon ekstrimis yang beredar massif di dunia maya yang berprinsip pada moderasi beragama bersama-sama dengan komunitas lain yang serupa seperti alifid dan nuonline. []

\section{Daftar Pustaka}

Balitbang Diklat Kementerian Agama. 2019. Buku Saku Tanya Jawab Moderasi Beragama. Jakarta: Kementerian Agama.
Borum, Randy. 2011. "Radicalization into Violent Extremism I: A Review of Social Science Theories." Journal of Strategic Security 4(4):7-36. doi: 10.5038/1944-0472.4.4.1.

Bowler, Gary M. 2010. "Netnography: A Method Specifically Designed to Study Cultures and Communities Online." The Qualitative Report 15(5):1270-75.

Denzin, Norman K, and Yvonna S. Lincoln. 2009. The SAGE Handbook of Qualitative Research. Thousand Oaks: SAGE Publications Inc.

Elam, Carol, Terry Stratton, and Denise D. Gibson. 2007. "Welcoming a New Generation to College: The Millennial Students." Journal of College Admission 15:20-25.

Fahri, Mohamad, and Ahmad Zainuri. 2019. "Moderasi Beragama di Indonesia." Intizar 25(2):95-100. doi: 10.19109/intizar.v25i2. 5640.

Fauzi, Ihsan Ali. 2019. Buku Panduan Melawan Hasutan Kebencian. Jakarta: Mafindo.

Fauziah, Siti Husnul. 2018. "Strategi Gerakan Arus Informasi Santri (AIS) Jogja dalam Menggerakkan Literasi Media Digital bagi Santri Pondok Pesantren." UIN Sunan Kalijaga, Yogyakarta.

Howe, Neil, and William Strauss. 2000. Millennials Rising: The Next Great Generation. New York: Vintage.

Iskandar, Hasyim. 2018. “Dakwah Komunitas Arus Informasi Santri (AIS) Banyuwangi Melalui Literasi Digital Santri." UIN Sunan Ampel, Surabaya.

Jones, Pip. 2010. Pengantar Teori-Teori Sosial dari Teori Fungsionalisme hingga Post-Modernisme. Jakarta: Yayasan Obor Indonesia.

Kagermann, Henning, Wolf-Dieter Lukas, and Wolfgang Wahlster. 2011. "Industrie 4.0: Mit dem Internet der Dinge auf Dem Weg Zur 4. industriellen Revolution." VDI Nachrichten 13(1):2-3. 
Kozinets, Robert V. 2002. "The Field behind the Screen: Using Netnography for Marketing Research in Online Communities." Journal of Marketing Research 39(1):61-72. doi: 10.1509/jmkr.39.1.61.18935.

Krekovic, Slavomir. 2003. "New Media Culture: Internet as a Tool of Cultural Transformation in Central and Eastern Europe." In Crossing Boundaries: From Syiria to Slovakia. Vienna: IWM Junior Visiting Fellows' ConferenceXIV(6):1-11.

Luntungan, Irving I. P., Aida Vitayala S. Hubeis, Euis Sunarti, and Agus Maulana. 2014. "Strategi Pengelolaan Generasi Y di Industri Perbankan." Jurnal Manajemen Teknologi 13(2):219-40. doi: 10.12695/jmt.2014. 13.2.7.

Monaco, Michele, and Malissa Martin. 2007. "The Millennial Student: A New Generation of Learners." Athletic Training Education Journal 2(2):42-46. doi: 10.4085/1947$380 \mathrm{x}-2.2 .42$

Nasrullah, R. 2017. Etnografi Virtual. Bandung: Simbiosa Rekatama Media.

Nasrullah, R. 2019. Teori dan Riset Khalayak Media. Jakarta: Prenadamedia.

Panjaitan, Poppy, and Arik Prasetya. 2017. "Pengaruh Social Media terhadap Pro- duktivitas Kerja Generasi Millenial (Studi pada Karyawan PT. Angkasa Pura I Cabang Bandara Internasional Juanda)." Jurnal Administrasi Bisnis 48(1):173-80.

Piliang, Yasraf Amir. 2003. Hipersemiotika: Tafsir Cultural Studies atas Matinya Makna. Yogyakarta: Jalasutra.

Prasetyo, Hoedi, and Wahyudi Sutopo. 2018. "Industri 4.0: Telaah Klasifikasi Aspek dan Arah Perkembangan Riset." Jurnal Teknik Industri 13(1):17-26. doi: 10.14710/jati. 13.1.17-26.

Ritzer, George. 2010. Teori Sosial Postmodern. Yogyakarta: Kreasi Wacana.

Turner, Bryan, ed. 2012. Teori Sosial dari Klasik sampai Postmodern. Yogyakarta: Pustaka Pelajar.

Wahana, Heru Dwi. 2015. "Pengaruh Nilai-Nilai Budaya Generasi Mellenial dan Budaya Sekolah terhadap Ketahanan Individu (Studi di SMA Negeri 39, Cijantung, Jakarta)." Jurnal Ketahanan Nasional 21(1):14-22. doi: 10.22146/jkn.6890.

Weinbaum, Cortney. 2016. The Millennial Generation: Implications for the Intelligence and Policy Communities. California: Rand Corporation. 